\title{
Quantification of peatland water storage capacity using the water table fluctuation method
}

\begin{tabular}{|r|l|}
\hline Journal: & Hydrological Processes \\
\hline Manuscript ID & HYP-16-0424.R2 \\
\hline Wiley - Manuscript type: & Research Article \\
\hline Complete List of Authors: & $\begin{array}{l}\text { Bourgault, Marc-Andre; UQAM Faculte des Sciences, Science de la terre et } \\
\text { de l'atmosphère } \\
\text { Larocque, Marie; University of Quebec at Montreal, Earth and atmospheric } \\
\text { Sciences } \\
\text { Garneau, Michelle; University of Quebec at Montreal, Geography }\end{array}$ \\
\hline Keywords: & $\begin{array}{l}\text { peatland, water storage, specific yield, water table fluctuation, drainage } \\
\text { experiment }\end{array}$ \\
\hline
\end{tabular}

SCHOLARONE ${ }^{\text {"m }}$

Manuscripts 
1 Quantification of peatland water storage capacity using

2 the water table fluctuation method

3 Marc-André Bourgault ${ }^{1,2^{*}}$, Marie Larocque ${ }^{1,2}$, Michelle Garneau ${ }^{2,3}$

4

$5{ }^{1}$ Département des sciences de la Terre et de l'atmosphère - Université du Québec à Montréal,

6 C.P. 8888, succ. Centre-Ville, Montréal (QC), Canada, H3C 3P8

$7{ }^{2}$ GEOTOP Research Center - Université du Québec à Montréal, C.P. 8888, succ. Centre-Ville,

8 Montréal (QC), Canada ; tel : 514-987-3000 ext. 1515 ; fax : 514-987-7749

$9{ }^{3}$ Département de Géographie- Université du Québec à Montréal, C.P. 8888, succ. Centre-Ville, 10 Montréal (QC), Canada, H3C 3P8

$12 *$ Corresponding author: bourgault.marc-andre@uqam.ca

\section{Abstract}

15 Peat specific yield $\left(\mathrm{S}_{\mathrm{Y}}\right)$ is an important parameter involved in many peatland hydrological 16 functions such as flood attenuation, baseflow contribution to rivers and maintaining 17 groundwater levels in surficial aquifers. However, general knowledge on peatland water 18 storage capacity is still very limited, due in part to the technical difficulties related to in 19 situ measurements. The objectives of this study were to quantify vertical $\mathrm{S}_{\mathrm{Y}}$ variations of

20 water tables in peatlands using the water table fluctuation method (WTF) and to better 21 understand the factors controlling peatland water storage capacity. The method was tested 22 in five ombrotrophic peatlands located in the St. Lawrence Lowlands (southern Québec, 23 Canada). In each peatland, water table wells were installed at three locations (up-gradient, 24 mid-gradient and down-gradient). Near each well, a $1 \mathrm{~m}$ long peat core $(8 \mathrm{~cm} \mathrm{x} 8 \mathrm{~cm})$ 25 was sampled, and sub-samples were used to determine $\mathrm{S}_{\mathrm{Y}}$ with standard gravitational 26 drainage method. A larger peat sample $(25 \mathrm{~cm} \times 60 \mathrm{~cm} \times 40 \mathrm{~cm})$ was also collected in 
27 one peatland to estimate $\mathrm{S}_{\mathrm{Y}}$ using a laboratory drainage method. In all sites, the mean 28 water table depth ranged from 9 to $49 \mathrm{~cm}$ below the peat surface, with annual fluctuations 29 varying between 15 and $29 \mathrm{~cm}$ for all locations. The WTF method produced similar 30 results to the gravitational drainage experiments, with values ranging between 0.13 and 310.99 for the WTF method, and between 0.01 and 0.95 for the gravitational drainage 32 experiments. $S_{Y}$ was found to rapidly decrease with depth within $20 \mathrm{~cm}$, independently of 33 the within-site location and the mean annual water table depth. Dominant factors 34 explaining $\mathrm{S}_{\mathrm{Y}}$ variations were identified using ANOVA. The most important factor was 35 peatland site, followed by peat depth and seasonality. Variations in storage capacity 36 considering site and seasonality followed regional effective growing degree days and 37 evapotranspiration patterns. This work provides new data on spatial variations of peatland 38 water storage capacity using an easily implemented method that requires only water table 39 measurements and precipitation data.

40 Key words: peatland, water storage, specific yield, water table fluctuation, drainage 41 experiment

\section{$42 \quad 2$ Introduction}

$43 \quad$ Peatlands play important hydrologic functions by attenuating flooding by storing 44 water during high precipitation events (Acreman and Holden, 2013), contributing to river 45 base flows (Bourgault et al., 2014) and maintaining groundwater levels in superficial 46 aquifers (McLaughlin et al., 2014). However, enhanced knowledge on quantification of 47 water storage capacity is needed to better understand these peatland hydrological 48 functions. In peatlands, peat storage capacity $(\mathrm{S})$ strongly varies within the first meter and 49 buffers water table fluctuations, flow velocities and evapotranspiration fluxes (White, 50 1932). For example, when the water table is high, flow velocities and evapotranspiration 51 fluxes increase; the opposite happens during low water table periods.

52 In mineral aquifers, long-term water storage is also controlled by climatic forcing 53 such as summer water deficits (Yeh et al., 2006), by anthropogenic activities such as 54 groundwater extraction, and to a more limited extent by land drainage which can reduce 55 aquifer recharge (Winter et al., 1998). Short-term changes occur mainly in response to 
56 rainfall, pumping, and evapotranspiration fluxes (Healy and Cook, 2002; Geris et al., 57 2015). These processes are also active in peatland ecosystems. They are especially 58 important due to the contrasted values of $\mathrm{S}$ between the acrotelm and the catotelm 59 (Ingram and Bragg, 1984). In addition, peat $\mathrm{S}$ also changes due to expansion and 60 compression, which is a seasonal effect of water content variation (also named mire 61 breathing; Price and Schlotzhauer, 1999), ice expansion in the peat, or a longer time scale 62 effect of organic matter oxidation. Therefore, water table fluctuation does not occur only 63 when air enters the specific yield $\left(\mathrm{S}_{\mathrm{Y}}\right)$ as the water table declines. However, as a first 64 approximation $\mathrm{S}$ is usually assimilated to $\mathrm{S}_{\mathrm{Y}}$ (Price, 1996).

65 Peat $\mathrm{S}_{\mathrm{Y}}$ can vary by up to two orders of magnitude $(0.01-1)$ within the first top $6650 \mathrm{~cm}$ (Vorob'ev, 1963; Holden, 2009; Dettmann and Bechtold, 2016). This buffers 67 peatlands against both inundation and excessive drying (Waddington et al., 2015). S has 68 been quantified based on field measurements using porous disk infiltrometers (Holden et 69 al., 2001; Holden, 2009), rain-to-rise ratio (Letts et al., 2000; McLaughlin and Cohen, 70 2014; Dettmann and Bechtold, 2016), tracer tests (Ronkanen and Klove, 2008), 71 laboratory drainage experiments (Vorob'ev, 1963; Price, 1996; Rosa and Larocque, 72 2008), and pressure chamber measurements (Moore et al., 2015). The rain-to-rise ratio 73 method is equivalent to the water table fluctuation method (WTF; White, 1932) 74 commonly used in aquifers to quantify groundwater recharge (Healy and Cook, 2002).

75 The WTF method is a simple alternative to laboratory measurements. It has 76 significant potential as an easily implemented, low-cost method to determine peat $\mathrm{S}_{\mathrm{Y}}$. 77 Because peat deposits are heterogeneous (Baird et al., 2015) and compressible media 78 where hysteresis is observed between water table rise and precipitation due to air 79 encapsulation, gas bubble production, and unsaturated pore filling (Nachabe, 2002; 80 Barton et al., 2006; Ramirez et al., 2015), we hypothesised that the WTF method is more 81 adapted to peatland than conventional laboratory measurements. The use of the WTF 82 method in peatlands, offers an excellent opportunity to upscale the understanding of 83 water storage capacity using widely available data of water table and precipitation. 
84 The objective of this research was to adapt the WTF method to quantify vertical $\mathrm{S}_{\mathrm{Y}}$ 85 variations in peatlands and better understand the factors controlling their water storage 86 capacity. It is assumed that seasonal expansion and compression expansion of peat do not 87 influence the short-term rain event-based calculation of $\mathrm{S}_{\mathrm{Y}}$. It is also assumed that 88 changes in peat surface topography following a single rain event can be considered 89 negligible. The WTF method was tested in five ombrotrophic peatlands located in the St. 90 Lawrence Lowlands in southern Quebec (Canada), and results were compared to $\mathrm{S}_{\mathrm{Y}}$ 91 estimates from laboratory measurements on collected peat samples.

\section{$92 \quad 3 \quad$ Study sites}

93 The five studied peatlands (Large Tea Field - LTF, Sainte-Séraphine - SSE, Lac 94 Cyprès - LCY, Victoriaville - VIC, Issoudun - ISO) are located in the southern part of 95 the St. Lawrence Lowlands (Quebec, Canada) in three different watersheds 96 (Châteauguay, Nicolet, and Du Chêne) (Figure 1). All sites are headwater peatlands 97 formed in topographic depressions, except LCY, which is located on the flank of fine to 98 medium aeolian sand deposits. All sites are characterized by a hummock and lawn 99 microtopography without any surface pools. Hollows and mud bottom were found only at 100 sites ISO and VIC.

101 The five sites are set in different geological contexts, characterized by quaternary 102 surficial sediments (marine clay, fluvial sandy silt, clayey silty till, aeolian fine to 103 medium sand, and regressive marine sand) deposited following the last deglaciation since 104 12,3 kaBP (Richard and Occhietti, 2004) (Table I). Peat thickness vary between $40 \mathrm{~cm}$ 105 and $522 \mathrm{~cm}$ with maximum of $190 \mathrm{~cm}$ in LCY, $522 \mathrm{~cm}$ in SSE, $493 \mathrm{~cm}$ in LTF, $345 \mathrm{~cm}$ 106 in VIC and $454 \mathrm{~cm}$ in ISO. Their surface range between 0.5 and $6.0 \mathrm{~km}^{2}$ (Table 1) and 107 they have developed as complexes with a central ombrotrophic section. Lateral 108 minerotrophic conditions were found only at site SSE.

109 Mean annual precipitation (reference period: 1981 - 2010) for the Châteauguay 110 (LTF), Nicolet (SSE, LCY, VIC), and du Chêne (Issoudun - ISO) watersheds varies 111 between $965 \mathrm{~mm}$ (Châteauguay) and $1114 \mathrm{~mm}$ (Nicolet), with the driest conditions 112 recorded in the LTF region specifically. For all sites (Figure 2), minimum monthly 
113 precipitation occurs during the winter, and maximum monthly precipitation occurs during 114 the summer (Environment Canada, 2015). Mean annual temperature (for the same 115 reference period as for mean annual precipitation) varies between $4.8^{\circ} \mathrm{C}$ and $6.7{ }^{\circ} \mathrm{C}$, with 116 the lowest values in the ISO region. For all sites, minimum and maximum temperatures 117 are recorded in January and July respectively (Figure 2). Effective growing degree days 118 (GGD $>0$ ) (reference period: 1974-2000) varies between 1800 and 2000 for the 119 Châteauguay watershed, between 1600 and 1800 for the Nicolet watershed, and between 1201400 and 1600 for the du Chêne watershed (Atlas agroclimatique du Québec, 2012) 121 (Table I).

122 Vegetation surveys performed at all sites show that Sphagnum spp. (Sph sp.), Kalmia 123 angustifolia (Kal ang), and Eriophorum vaginatum (Eri vag) are the main species. 124 Andromeda glaucophylla (And gla), Aulacomnium palustre (Aul pal), Chamaedaphne 125 calyculata (Cha cal), Carex spp. (Car sp.), Rhododendron groenlandicum (Rho gro), and 126 Polytricum strictum (Pol str) were also found, albeit sparsely (Larocque et al., 2015; 127 Lefebvre et al., 2015; Pasquet et al., 2015). Climatic conditions differ slightly from west 128 to east, in terms of effective growing degree days and ecoregion vegetation assemblages, 129 from the hickory and maple forest (Carya cordiformis and Acer saccharum) in the 130 western section (LTF), to the lime tree and maple forest (Tilia americana and Acer 131 saccharum) eastward, which supports the slightly colder and wetter conditions of the ISO 132 site.

\section{Methodology}

\section{$134 \quad 4.1$ Site instrumentation}

135 Elevation data were obtained for the five sites from a Digital Elevation Model 136 (DEM; 1 x 1 m resolution) derived from airborne light detection and ranging (LiDAR) 137 surveys. Absolute errors on elevations vary between 5 and $48 \mathrm{~cm}$ (Hodgson and 138 Bresnahan, 2004; Aguilar et al., 2010), with the smallest errors for open areas. Based on 139 the DEM, three locations were identified in each peatland (up-gradient, mid-gradient, and 140 down-gradient) for the installation of wells (Figure 3). Distances between up-gradient and 
141 down-gradient wells vary between 123 and $760 \mathrm{~m}$ with mean slopes from $0.08 \%$ to $142 \quad 0.24 \%$ (Table 1$)$.

143 Water table variations were recorded at these three locations within each site using 144 wells constructed from $3 \mathrm{~cm}$ OD PVC pipes, with $2 \mathrm{~m}$ long intakes perforated with $1450.0254 \mathrm{~cm}$ slits from top to bottom, and sealed at their base. All wells were inserted into 146 Sphagnum lawn microforms. Sites were also equipped with three level loggers (Solinst), 147 a barometric logger (Solinst), and a rain gauge tipping bucket (Hobo). The level loggers 148 and barometric loggers were attached to the well screw tops. Water table variations, 149 barometric pressure, and precipitation were measured every 5 minutes from June 2014 to 150 August 2015 (with the exception of the winter months between November 2014 and 151 April 2015). Sites were also instrumented with a metal bar at down-gradient locations to 152 monitor changes in topography due to peat expansion and contraction. These changes 153 were monitored three times during the study period (spring, summer, and autumn) using a 154 reference level located on the metal bars.

\section{$155 \quad 4.2$ Small cube experiment}

$156 \quad$ Five $1 \mathrm{~m}$ long peat cores were sampled using a Box corer (8 x $8 \mathrm{~cm}$ ) (Jeglum, 1991) 157 at the up-gradient location of each studied peatland. Sampling compression in the 158 acrotelm was $10 \mathrm{~cm}$ for LTF, $12 \mathrm{~cm}$ for SSE, $20 \mathrm{~cm}$ for LCY, $8 \mathrm{~cm}$ for VIC, and $2 \mathrm{~cm}$ for 159 ISO, and were proportional to the acrotelm thickness. Cores were cut into two $50 \mathrm{~cm}$ 160 sections using a sharp knife, wrapped in cellophane, and stored at $4{ }^{\circ} \mathrm{C}$. Humification 161 analysis was performed on $5 \mathrm{~cm}$ peat slices throughout the whole 5 cores. $\mathrm{S}_{\mathrm{Y}}$ 162 measurements were performed on $7 \times 7 \times 8 \mathrm{~cm}$ peat samples (14 cores in total; 3 for LTF, 1633 for SSE, 2 for LCY, 3 for VIC and 3 for ISO) using gravity drainage experiments 164 assuming that $S_{Y}$ can be assimilated to its drainable porosity (Price, 1996).

165 Gravity drainage was performed in acrylic cubes $(7 \times 7 \times 8 \mathrm{~cm})$ and used to estimate 166 S following Eq. (1) (Freeze and Cherry, 1979),

$$
S_{Y}=\frac{V_{d}}{A * \Delta h}
$$


168 where $\mathrm{V}_{\mathrm{d}}$ is the drained water volume $\left(\mathrm{cm}^{3}\right)$, $\mathrm{A}$ is the area of the peat sample $169\left(7 \mathrm{~cm} \mathrm{x} 7 \mathrm{~cm}=49 \mathrm{~cm}^{2}\right)$, and $\Delta \mathrm{h}$ is the water table fluctuation $(\mathrm{cm})$. Peat samples were 170 resized after $0.5 \mathrm{~cm}$ was cut from each side to remove any compression due to 171 transportation. Samples were saturated for 24 hours and drained for an additional 24 172 hours. Each acrylic cube was connected at the bottom to a $1.3 \mathrm{~cm}$ plastic tube attached to 173 an adjustable base support to drain the samples. Each drainage experiment began by 174 decreasing the height of the plastic tube to that of the bottom of the tested sample. 175 Although slightly different from conventional drainage experiments, this method was 176 specifically chosen so as to be comparable to the experimental tank method described in 177 section 4.3.

178 For the less decomposed samples, the errors were proportional to the lost volume due 179 to compression above the water table. Errors were calculated using the ratio between the 180 loss of height and the mean annual water table depth since compression was limited to 181 the unsaturated zone. Since compression was not evenly distributed throughout the core, 182 errors on $\mathrm{S}_{\mathrm{Y}}$ measurement were only applied to the upper $20 \mathrm{~cm}$.

183 For the more decomposed samples (below $20 \mathrm{~cm}$; all the sites), rapid outflow was 184 observed, probably due to secondary porosity created during sample insertion into the 185 acrylic cubes. The rapid outflow was measured at the beginning of each experiment and 186 divided by the total volume of the acrylic cubes $(7 \times 7 \times 8 \mathrm{~cm})$ to quantify the maximum 187 error associated with the method.

\section{$188 \quad 4.3$ Experimental tank}

189 The laboratory method developed by Rosa and Larocque (2008) to estimate $\mathrm{S}_{\mathrm{Y}}$ was 190 adapted to quantify the fine-scale, empirical relationship between $\mathrm{S}_{\mathrm{Y}}$ and depth below the 191 peat surface. Laboratory experiments were conducted in a $40 \mathrm{~cm}$ long, $25 \mathrm{~cm}$ wide, and $19236 \mathrm{~cm}$ high experimental tank built using $4 \mathrm{~mm}$ thick clear acrylic panels (Figure 4 ). The 193 peat sample was retrieved from the LTF peatland at the up-gradient location. The mean 194 water table depth $(26 \mathrm{~cm})$ at this site is equivalent to that of the four other studied 195 peatlands, making it representative of all sites for this experiment. No compression was 196 observed during sampling. 
197 In the laboratory, the two sides of the peat sample were supported with perforated 198 stainless steel plates to create two experimental reservoirs. These reservoirs were 199 connected using flexible $5.1 \mathrm{~cm}$ PVC tubing, and redirected to a single outlet to control 200 water table elevation within the reservoirs. The tank was filled from the bottom with 201 water collected in the field with 4 L Nalgene bottles. A neon lamp suspended $15 \mathrm{~cm}$ 202 above the tank provided $12 \mathrm{~h}$ of daylight to maintain living vegetation conditions.

203 Drainage experiments were performed every centimetre between 0-20 cm, and every $2042.5 \mathrm{~cm}$ between 20-36 cm. Drainage intervals were increased below $20 \mathrm{~cm}$ so as to 205 reduce volumetric error measurements since $S_{Y}$ and drained water decrease with depth 206 below the peat surface. Drainage experiments were performed twice for the upper $20 \mathrm{~cm}$ 207 to account for air encapsulation and unsaturated pore filling (Nachabe, 2002; Barton et 208 al., 2006). No compression or expansion resulting in a change of the peat elevation was 209 observed during the drainage experiments.

$210 \quad \mathrm{~S}_{\mathrm{Y}}$ estimates were obtained using Eq. 1, as defined in section 4.2 above, but with an $211 A=40 \mathrm{~cm} \times 25 \mathrm{~cm}=1000 \mathrm{~cm}^{2}$. However, $\mathrm{S}_{\mathrm{Y}}$ could not be estimated below 0.08 , due to 212 an increase in volumetric error measurements associated with the decreasing water 213 volume released from the drainable porosity and to bottom sedimentation within the two 214 reservoirs.

\section{$215 \quad 4.4$ Water table fluctuation method}

216 Using the WTF method, specific yield $\left(\mathrm{S}_{\mathrm{Y}}\right)$ was calculated as follows:

$217 \quad S_{Y}=P / \Delta h$

218 where $\mathrm{P}$ is the amount of precipitation, and $\Delta \mathrm{h}$ is the water level rise following a 219 precipitation event. Eq. (2) assumes that the time lag between the end of each 220 precipitation event and the maximum water level rise is sufficiently short for 221 evapotranspiration, net subsurface flow and water table recession following P events (i.e., 222 water reaching the saturated zone is entirely transferred into storage). The method also 223 assumes that recharge is equal to precipitation (i.e., no runoff), that the static equilibrium 224 water content profile within the unsaturated zone is attained instantaneously following a 
225 rain event and that any rain-to-rise ratio deviation from a theoretical model will be due to 226 the presence of a capillarity fringe, air entrapment, peat expansion and contraction, net 227 subsurface flow, water recession following $\mathrm{P}$ events and antecedent moisture content of 228 the unsaturated zone.

229 A computation script written in the $R$ language $(R, 2008)$ was developed to identify 230 the precipitation events to be considered and the maximum water table rise following 231 each precipitation event. The program automatically calculated total precipitation during 232 a given event $(\mathrm{P})$, maximum water level rise following this event $(\Delta \mathrm{h})$, and $\mathrm{S}_{\mathrm{Y}}$ using three 233 parameters: the time interval (Time $\left.{ }_{i n t}\right)$, the maximum $\left(\max _{\text {prec }}\right)$ and minimum 234 precipitation $\left(\min _{\text {prec }}\right)$. Time $\mathrm{Tint}_{\text {t }}$ was used to separate precipitation events. Max $\mathrm{Mrec}_{\text {and }}$ $235 \min _{\text {prec }}$ were used to determine which precipitation events to include in the $\mathrm{S}_{\mathrm{Y}}$ calculation. 236 Small precipitation events were excluded based on the assumption that a large proportion 237 of the precipitation never reached the saturated zone during these events. Large 238 precipitation events were also excluded since they induced large $\Delta \mathrm{h}$ with depth 239 approximation error. Measurement errors on $\Delta \mathrm{h}$ were equal to $1 \mathrm{~mm}$ whereas $\mathrm{P}$ errors are 240 estimated to be as high as $6.4 \%$ of total $\mathrm{P}$ for small rain events (Chiah, 2003; 241 Hodgkinson et al., 2004). Therefore, precipitation events smaller than $1 \mathrm{~mm}$ and larger 242 than $35 \mathrm{~mm}$, and those associated with water table variations smaller than $10 \mathrm{~mm}$ were 243 excluded, since the relative error on rain to rise ratio (equivalent to $S_{Y}$ ) was too large in 244 these cases.

245 While calibrating the R program, variations with Time int $_{\text {were set between } 1 \text { and } 10}$ 246 hours, $\max _{\text {prec }}$ between $20-100 \mathrm{~mm}$ and $\min _{\text {prec }}$ between 0-10 $\mathrm{mm}$. These intervals were 247 chosen since precipitation events between 10 and $20 \mathrm{~mm}$ easily reached the saturated 248 zone and were well constrained vertically. Time ${ }_{\text {int }}, \max _{\text {prec}}$, and $\min _{\text {prec }}$ were calibrated to 249 minimize the residual sum of squared errors (RSSE) between the model estimation, using $250 \mathrm{~S}_{\mathrm{Y}}$ obtained from the WTF method, and the individual laboratory $\mathrm{S}_{\mathrm{Y}}$ values, obtained 251 using the small cube experiment and the experimental tank method, while seeking to 252 retain a maximum number of precipitation events. A minimal value of Time $\mathrm{int}_{\mathrm{in}}$ was used to 253 support the hypothesis that subsurface flow was negligible and that the night-time

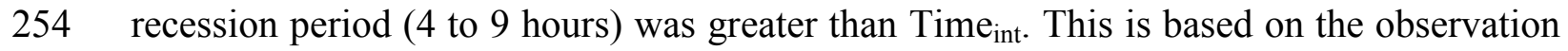


255 that the time lag between the end of a precipitation event and the maximum water table 256 increase was less than 3 hours (mean of 2 hours) for all rainfall events.

257 For all-time series analysis, Time ${ }_{\text {int }}, \max _{\text {prec }}$, and $\min _{\text {prec }}$ were set to 3 hours, $35 \mathrm{~mm}$ 258 and $7 \mathrm{~mm}$, respectively. Time series were resampled at 10, 20, 30, 40, and $60 \mathrm{~min}$, and 259 one day time intervals to identify the maximum time step required to calculate $\mathrm{S}_{\mathrm{Y}}$. 260 Modification of the selected time intervals had no effect on $\mathrm{S}_{\mathrm{Y}}$ calculation, except for the 261 one day time interval. To optimize calculations, the one hour time series interval was 262 used for all $\mathrm{S}_{\mathrm{Y}}$ calculations.

263 All $\mathrm{S}_{\mathrm{Y}}$ calculated using the WTF method $\left(\mathrm{S}_{\mathrm{Y}}\right.$ WTF $)$ were compared between sites, 264 depths, location within the peatland, and seasonality, using one-way Analysis of Variance 265 (ANOVA) implemented in R. Significant differences found among these variables were 266 further analyzed using Tukey's Honest Significant difference (HSD), again in R. Finally, 267 all $\mathrm{S}_{\mathrm{Y}}$ and rates of $\mathrm{S}_{\mathrm{Y}}$ decrease with depth obtained from the WTF, the experimental tank, 268 and the small cube experiment methods were compared.

\section{Results}

\subsection{Surface topography, hydrology and peat humification}

271

At all locations in the five studied peatlands, the upper $5 \mathrm{~cm}$ was composed of living 272 vegetation while peat was slightly humified between 10 and $20 \mathrm{~cm}$ below the surface 273 (H3-H4; (Von Post, 1922). Peat humification increased toward the catotelm, with highly 274 decomposed peat (H7- H8-H9) for sites VIC, LCY, LTF, and SSE, and slightly to 275 moderately decomposed peat (H4-H5) for site ISO.

276 Throughout the five peatlands, water table depths (WTD) varied between 1 and 60 $277 \mathrm{~cm}$, with a maximum measured variation of $19 \mathrm{~cm}$ in LCY, $26 \mathrm{~cm}$ in SSE, $24 \mathrm{~cm}$ in LTF, $27815 \mathrm{~cm}$ in VIC, and $19 \mathrm{~cm}$ in ISO. With the exception of VIC, WTD decreased from the 279 up-gradient to the down-gradient locations (Figure 5). Mean WTD for all sites combined 280 varied between 9 and $49 \mathrm{~cm}$ for up-gradient locations, between 12 and $33 \mathrm{~cm}$ for mid281 gradient locations, and between 6 and $44 \mathrm{~cm}$ for down-gradient locations. Mean WTD for 282 all locations in a given site in 2014 and 2015 were $41 \mathrm{~cm}$ in LCY, $37 \mathrm{~cm}$ in SSE, $26 \mathrm{~cm}$ 
283 in LTF, $19 \mathrm{~cm}$ in VIC, and $9 \mathrm{~cm}$ in ISO. Acrotelm thickness varied between $35 \mathrm{~cm}$ and $28455 \mathrm{~cm}$ (comprised value of humification lower than H5) with mean acrotelm thickness 285 equaled to $55 \mathrm{~cm}$ for LCY, $50 \mathrm{~cm}$ for SSE, $45 \mathrm{~cm}$ for LTF, $30 \mathrm{~cm}$ for VIC and $45 \mathrm{~cm}$ for 286 ISO.

287

288

289

290

291

292

5.2 Specific yield estimated using the small cube method experiment and experimental tank measurements

293

The $\mathrm{S}_{\mathrm{Y}}$ values estimated using the cube $\left(\mathrm{S}_{\mathrm{Ycube}}\right)$ and the tank $\left(\mathrm{S}_{\mathrm{Ytank}}\right)$ methods varied 294 from 0.01 and 0.95 within the first meter $\left(S_{Y c u b e}\right.$ and $S_{Y \operatorname{tank}}$ cannot exceed 1.0) (Figure 6).

295 The mean $\mathrm{S}_{\text {Ytank }}$ and $\mathrm{S}_{\text {Ycube }}$ of the living and slightly humified peat layer comprised within 296 the acrotelm was 0.69 and 0.35 for the two methods respectively. For the cube method, $297 S_{Y}$ rates decreased with depth, varying between 0.001 and $0.030 \mathrm{~cm}^{-1}$. The upper $\sim 25 \mathrm{~cm}$ 298 showed rates of decrease varying from $0.015 \mathrm{~cm}^{-1}$ to $0.030 \mathrm{~cm}^{-1}$, whereas the rate of 299 decrease between $25 \mathrm{~cm}$ and $100 \mathrm{~cm}$ is indistinguishable from $0 \mathrm{~cm}^{-1}$. The average $\mathrm{S}_{Y}$ 300 measurement error for the small cube experiment on the 0-20 cm samples was 0.49 for 301 LCY, 0.32 for SSE, 0.38 for LTF, 0.42 for VIC and 0.22 for ISO, with an overall mean of 302 0.37. The average $\mathrm{S}_{\mathrm{Y}}$ measurement error due to this manipulation was estimated to be $3030.05(\mathrm{n}=40)$, with a maximum value of 0.11 . For the experimental tank method, the rate 304 of $S_{Y}$ decrease with depth is $0.07 \mathrm{~cm}^{-1}$ between 10 and $25 \mathrm{~cm}$, and $0.005 \mathrm{~cm}^{-1}$ for the 305 bottom sections $(25-30 \mathrm{~cm})$. While modeling $\mathrm{S}_{\mathrm{Ytank}}$ as a function of depth, $\mathrm{S}_{\mathrm{Ytank}}$ between 3060 and $10 \mathrm{~cm}$ were not considered due to the lack of variation with depth associated with 307 the living vegetation.

308 Between $0 \mathrm{~cm}$ and $20 \mathrm{~cm}, \mathrm{~S}_{\text {Ycube }}$ measurements were considerably lower than $\mathrm{S}_{\text {Ytank, }}$ 309 probably due to peat compression during coring for $\mathrm{S}_{\text {Ycube }}$ which varied between 2 and $31020 \mathrm{~cm}$. No compression was observed during sampling for the tank experiment. Hence, 311 the $S_{\text {Ycube }}$ measurements should be considered to represent the lower boundary of the true 
$312 \mathrm{~S}_{\mathrm{Y}}$ values. Even if these data should not be used as absolute values, they suggest a non313 linear trend of $\mathrm{S}_{\mathrm{Y}}$ with respect to depth.

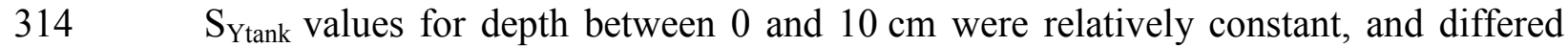
315 considerably from the values obtained at greater depth. This is consistent with the greater 316 peat humification below $10 \mathrm{~cm}$, which changed from poorly humified $(\mathrm{H} 1-\mathrm{H} 2)$ above $31710 \mathrm{~cm}$ to slightly humified (H3-H4) below.

318 Different regression models for the $\mathrm{S}_{\mathrm{Y}}$ vs depth relationship (i.e., linear, log, and 319 power law) were calculated. Similar to the work of Sherwood et al. (2013), the best fit 320 model for both methods were power law models:

$321 \quad S_{Y}=\beta_{0} \operatorname{depth}^{-\beta_{1}}$

322 where $\beta_{0}=1.45$ and $\beta_{1}=-0.75$, with resulting $\mathrm{RSSE}=0.62$ for the small cube method, 323 and where $\beta_{0}=41.41$ and $\beta_{1}=1.58$, with resulting RSSE $=0.19$ for the experimental tank 324 method. These power law models are used henceforth to describe $\mathrm{S}_{\mathrm{Y}}$ changes with depth. 325 However, the rate of $\mathrm{S}_{\mathrm{Y}}$ decrease with depth needs to be adjusted for each peatland since 326 the mean water table depth and acrotelm thickness can vary between peatlands.

\section{$327 \quad 5.3$ Specific yield estimated using the WTF method}

328 During 2014 and 2015, a total of 1182 precipitation events were recorded, ranging 329 between 1 and $57.2 \mathrm{~mm}$, with a mean of $5 \mathrm{~mm}$, and precipitation intensity varying 330 between 0.2 to $27.6 \mathrm{~mm} /$ hour. During this period, $\Delta \mathrm{h}$ values varied from 10 to $178 \mathrm{~mm}$. 331 Following a rain event, the calculated $\mathrm{S}_{\mathrm{Y}}$ WTF varied between 0.02 and 2, with a mean of 3320.59 (Figure 7). A total of 99 precipitation events (13\%) generated $\mathrm{S}_{\mathrm{Y}}$ WTF values 333 exceeding 1, 183 (24\%) resulted in $\mathrm{S}_{\mathrm{Y}}$ WTF values between 0.59 and 1, and 465 (63\%) 334 resulted in $\mathrm{S}_{\mathrm{Y}}$ values smaller than 0.59 . Values of $\mathrm{S}_{\mathrm{Y} \text { WTF }}$ above 1 were not considered in 335 the analysis since they did not respect the hypothesis that runoff was negligible.

$336 \quad \mathrm{~S}_{\mathrm{Y}}$ WTF values were highly variable between sites, with values between 0.32 and 0.99 337 for ISO, 0.18 and 0.99 for VIC, 0.13 and 0.99 for LTF, 0.25 and 0.90 for SSE, and 0.29 338 and 0.88 for LCY (Figure 8 ). The best fit power law equation for the $\mathrm{S}_{\mathrm{Y}}$-depth models 
339 used $\beta_{0}$ ranging from 6.69 to 2783.01 and $\beta_{1}$ from -0.94 to -2.23 . Modeled rates of $S_{Y}$

340 decrease with depth varied between $0.008 \mathrm{~cm}^{-1}$ and $0.06 \mathrm{~cm}^{-1}$ for all sites, with a higher 341 rate of decrease when water table levels were high. The rate of $S_{Y}$ decrease with depth 342 shows similar patterns across all sites.

343 Results from the ANOVA showed that site, seasonality, within-site location, and 344 depth have a significant effect on $S_{Y}$. Site $(p<0.0001)$, depth $(p<0.0001)$, and 345 seasonality $(\mathrm{p}=0.007)$ were the strongest factors, while location within the peatland was 346 the weakest $(p=0.05$; Figure 9).

347 Considering site (Figure 9a), LCY, VIC, and ISO show no significant difference in 348 their median $\mathrm{S}_{\mathrm{Y}}$, whereas LTF and SSE, differ strongly from LCY, VIC, and ISO 349 (confidence interval of 99\%). For depth (Figure 9b), groups of 0-5, 5-10, and 10-15 cm 350 show higher calculated $\mathrm{S}_{\mathrm{Y}}$ than deeper groups. However, there are no systematic 351 significant differences between all depth groups. For seasonality (Figure 9c), $\mathrm{S}_{\mathrm{Y}}$ varies 352 following the seasons and shows no significant difference during the wet periods (May, 353 June, October, and November). Finally, the ANOVA results indicated that within-site 354 location was not a dominant factor since no statistical difference was found between the 355 up-gradient, mid-gradient, and down-gradient locations when comparing the different 356 locations in a given peatland or when merging all the sites (Figure 9d).

\section{Discussion}

\section{$358 \quad 6.1$ Specific yield measurements}

359 The $\mathrm{S}_{\mathrm{Y}}$ measurements and rates of decrease obtained in this study were generally 360 consistent with the range of values reported for different types of wetlands (peatland, 361 blanket peat, open water, constructed peatland, cutover bog) and using different methods 362 (e.g., gravity drainage, moisture retention measurements, infiltration rate experiment, 363 water table fluctuation method, tracer tests) (Table II). Using the WTF method, Moore et 364 al. (2015), McLaughlin and Cohen (2014), and Dettmann and Bechtold (2016) reported $365 S_{Y}$ values ranging from 0 to 1.1 , from 0.13 to 1.05 and 0 to 0.9 within the first 50,65 and $36645 \mathrm{~cm}$ respectively. This was equivalent to rates ranging between $\sim 0.007-0.013 \mathrm{~cm}^{-1}$ 
367 (Moore et al., 2015), $0.02 \mathrm{~cm}^{-1}$ (McLaughlin and Cohen, 2014) and $\sim 0-0.08 \mathrm{~cm}^{-1}$

368 (Dettmann and Bechtold, 2016). Using pressure chamber experiment measurements as 369 quantitatively equivalent to $S_{Y}$, Moore et al. (2015) found that $S_{Y}$ varied between 0.1 and 3700.7 , at a rate ranging between 0.007 and $0.013 \mathrm{~cm}^{-1}$. With infiltration measurements, 371 Holden (2009) found that $S_{Y}$ varied between 0.01 and 1.00 within the upper $20 \mathrm{~cm}$, 372 independently of the surface vegetation (with the exception of Eriophorum, where it 373 reached 0.001). This is equivalent to a decrease in $\mathrm{S}_{\mathrm{Y}}$ with depth of between $\sim 0.02$ and $\sim$ $3740.05 \mathrm{~cm}^{-1}$. Finally, using gravity experiments, Vorob'ev (1963) investigated $\mathrm{S}_{\mathrm{Y}}$ and the 375 relationship between capillarity fringe and gravitational moisture in unforested low-lying 376 swamps (the term used by the author to designate peatlands), and found that $S_{Y}$ decreased 377 non-linearly with depth, from $\sim 0.09$ to $\sim 0.45$, at a rate of $\sim 0.04$ to $0.06 \mathrm{~cm}^{-1}$ (Table II). In 378 this study, $\mathrm{S}_{\mathrm{Y}}$ varied between 0.13 and 0.99 using the WTF method and between 0.01 and 3790.95 using the small cube and tank drainage experiments. These results are strong 380 observational evidence of the sharp decrease of $S_{Y}$ with depth. Moreover, results obtained 381 using the WTF method show almost identical ranges and patterns obtained by Dettmann 382 and Bechtold (2016).

\section{$383 \quad 6.2$ Comparison of methods}

384 In this work, the cube method and the experimental tank were combined to determine 385 the fine scale variations of $\mathrm{S}_{\mathrm{Y}}$ as a function of depth within the top peat deposit 386 (experimental tank) and the general patterns of $\mathrm{S}_{\mathrm{Y}}$ as a function of depth throughout the 387 peat column (cube method). The sampling process can induce artificial modifications to 388 the peat. For instance, the use of a box corer to sample peat is an imperfect method, 389 especially in peatlands with a thick acrotelm layer that can be easily compressed. 390 However, the box corer provides the capacity to sample deeper peat cores, thus providing 391 insight into the values of $S_{Y}$ lower within the peat column. Sampling the larger peat 392 volume required for the experimental tank induces minimal peat compression, but 393 addressed only on the top peat layer. Moreover, $S_{Y}$ measurements are commonly 394 performed directly in the laboratory on samples that have different volumes or in the field 395 where it is hard to evaluate the scale of the measurements. In fact, strong heterogeneity of 396 hydrodynamic properties are constantly encountered at very small scale and expected to 
397 modify measurements and induce a scale effect (Turner et al., 2015). Hence, it is 398 expected that $\mathrm{S}_{\mathrm{Y}}$ obtained in the laboratory will disagree with $\mathrm{S}_{\mathrm{Y}}$ measurements obtained 399 with in situ methods.

400 Comparing results from the three different methods remains challenging also because 401 they depart slightly from the $\mathrm{S}_{\mathrm{Y}}$ definition. For example, the drainage experiments (small 402 cubes and tank) measure drainage porosity which is an approximation of $\mathrm{S}_{\mathrm{Y}}$. 403 Nevertheless, given the fact that the WTF method provided $\mathrm{S}_{\mathrm{Y}}$ values similar to those of 404 the cube method and of the experimental tank and that the results obtained in this study 405 are almost identical to the results obtained by Dettmann and Bechtold (2016) using the 406 same method, it is hypothesized that the assumption underlying the use of the WTF 407 method are reasonable. In future research, the WTF method will need to be used in a 408 wide variety of peatlands to fully constrain its validity.

$409 \quad 6.3$ Factors influencing storage capacity variations

$410 \quad$ Many authors (Moore et al., 2015; Thompson and Waddington, 2013; Holden, 2009; 411 Price, 1996) have demonstrated that peatlands vary significantly in terms of 412 microtopography (hummock, lawn, hollow, pool), disturbances (fire, drainage), 413 hydrogeological context, and hydroclimatic environment (Geris et al., 2015). These are 414 all factors that have been recognized as affecting storage capacity. Fires have been shown 415 to decrease $\mathrm{S}_{\mathrm{Y}}$, which increases the flashiness of water table fluctuations (Sherwood et 416 al., 2013). $\mathrm{S}_{\mathrm{Y}}$ differ between hummocks and hollows as these tend to dry up more rapidly 417 and retain more water than hummocks (Moore et al., 2015). Hydrogeological contexts 418 control the connectivity of peatlands to aquifers, limiting water table fluctuations (i.e., 419 minerotrophic peatland), and hydroclimatic conditions modify precipitation regimes, 420 evapotranspiration, and soil moisture dynamics, exerting a control on water storage 421 (Geris et al., 2015).

422 In this study, observed $\mathrm{S}_{\mathrm{Y}}$ differences could not be explained by the presence of 423 disturbances or variations in microform, since vegetation assemblages did not show 424 strong evidence of perturbation and microforms did not differ significantly within and 425 between sites. Additionally, the hydrogeological context, which was found to differ 
426 strongly from site to site (Table I) could not explain the increasing $\mathrm{S}_{\mathrm{Y}}$ trend observed in 427 Figure 9a. LCY and VIC have both developed on fine to medium sand (high 428 permeability), whereas ISO formed on glacial clayed silt (low permeability), yet no 429 statistical difference was found between their means.

430 Between site locations, differences in storage capacity are better explained by the 431 decreasing trend in effective growing degree days registered from the south-west to the 432 north-east St. Lawrence Lowlands. Higher numbers of effective growing degree days 433 increase overall evapotranspiration rates. Sites characterized by greater 434 evapotranspiration tend to have water tables closer to their respective minimum annual 435 water table position, where humification is higher. Therefore, under similar precipitation 436 regimes, those sites experiencing higher evapotranspiration rates will have lower $\mathrm{S}_{\mathrm{Y}}$ wTF. 437 However, their dynamic storage capacity will be higher, since more space is available 438 before reaching a threshold water-table depth.

439 Large variations in $\mathrm{S}_{\mathrm{Y}}$ with depth within the peat profile (Figure $9 \mathrm{~b}$ ) have also been 440 reported in the literature (Moore et al., 2015; Holden, 2009; Vorob'ev, 1963), and 441 correspond to the increasing degree of peat decomposition with depth. For instance, a $\mathrm{S}_{\mathrm{Y}}$ 442 of greater than 0.13 is equivalent to a Von Post degree of decomposition between $\mathrm{H} 1$ and $443 \mathrm{H}$, whereas a $\mathrm{S}_{\mathrm{Y}}$ of less than 0.13 is equivalent to a degree of decomposition between $\mathrm{H6}$ 444 and H9. This link between $\mathrm{S}_{\mathrm{Y}}$ and degree of decomposition has also been reported by 445 Letts et al. (2000), where $\mathrm{S}_{\mathrm{Y}}$ decreased from 0.66 to 0.13 , with peat type changing from 446 fibric to sapric, and by Boelter (1964), who reported $\mathrm{S}_{\mathrm{Y}}$ as high as 0.80 in undecomposed 447 peat and as low as 0.10 in highly decomposed peat. However, results from the current 448 study show that depth is not a systematic explanatory factor when all sites were 449 considered together. Similar Sy wTF distributions with depth were observed for all sites, 450 independently of the mean annual WTD of each. For example, at LCY where mean 451 annual WTD is $41 \mathrm{~cm}$, Sy WTF is almost identical to that of ISO, where mean annual 452 WTD is only $9 \mathrm{~cm}$. Therefore, mean annual WTD should not be considered to be a proxy 453 of peatland water storage capacity. 
454 Seasonality is another important control on dynamic storage capacity (Figure 9c). 455 Indeed, median $\mathrm{S}_{\mathrm{Y}}$ WTF is higher during wet periods compared to dry periods. This is 456 explained by the fact that evapotranspiration rates are higher during dry periods 457 compared to wet periods. Moreover, these results are consistent with recent findings by 458 Geris et al. (2015), showing that tree cover temporarily increases the dynamic storage 459 capacity during summer due to higher evapotranspiration.

460 The absence of a within-site location effect on $\mathrm{S}_{\mathrm{Y} \text { WTF }}$ in this study (Figure 9d) has 461 strong implications for future research. The absence of spatial variation within the studied 462 sites suggests that a single $\mathrm{S}_{\mathrm{Y}}$-depth model could be sufficient to represent a given site. 463 However, more research is needed to better understand the vertical $\mathrm{S}_{\mathrm{Y}}$ variation of the 464 water table fluctuation layer, due to the various hydrogeological contexts and 465 microforms.

\section{$466 \quad 6.4$ Implications for peatland understanding and management}

467 Results from this study have many hydrological implications in terms of 468 hydrological modelling, evapotranspiration feedback, WT-climate linkage, and 469 understanding peatland water storage capacity at the local and global scales. Many 470 authors have studied overland and rapid/slow subsurface flow within peatlands to 471 quantify peatland-surface water interactions (Devito et al., 1997; Reeve et al., 2000; 472 Reeve et al., 2001; Holden et al., 2008). The WTF method provides a means to quantify 473 the $\mathrm{S}_{\mathrm{Y}}$, and therefore to better understand the timing and the transition between overland 474 and subsurface flow within peatlands. Two previously established (McLaughlin and 475 Cohen, 2014) $\mathrm{S}_{\mathrm{Y}}$ ranges were also observed in this study: greater than 1, and between 0 476 and $1 . \mathrm{S}_{\mathrm{Y}}$ values greater than 1 indicate additional water input from uphill or from the 477 redistribution of precipitation within the peatland. When $S_{Y}$ is between 0 and 1, 478 precipitation accumulates within the pore spaces until a threshold, where pore sizes of 479 undecomposed peat are too large to hold more water (Holden, 2009). Somewhat 480 counterintuitively, this can be interpreted as indicating that the water table does not need 481 to reach the surface to be characterized by a $S_{Y \text { WTF }}$ of greater than 1. 
Peatland water storage capacity is an important component of flood mitigation 483 (Acreman and Holden, 2013). The results obtained with the WTF method offer new data 484 that could be very useful for short term transient hydrological/hydrogeological models. A 485 single model of vertical $\mathrm{S}_{\mathrm{Y}}$ could be used in physically-based models to simulate peatland 486 dynamics (Reeve et al., 2006). This could lead to more accurate estimates of the delay 487 between precipitation and river floods in watersheds containing large peatland coverage. 488 However, using long-term transient hydrological models requires a thorough 489 understanding of the effect of swelling/shrinking peat soils on water storage capacity 490 (Camporese et al., 2006) which is rarely available.

\section{Conclusion}

492 The objective of this study was to adapt the WTF method in order to quantify 493 vertical $S_{Y}$ variations in peatlands and to better understand the factors controlling 494 peatland water storage capacity. This objective was achieved by comparing results from 495 laboratory experiments on small and intermediate-size peat samples with results from the 496 WTF method. The methods were carried out on five peatlands of the St. Lawrence 497 lowlands, at three different locations within each peatland.

498 Although uncertainties in $\mathrm{S}_{\mathrm{Y}}$ were identified for the cube samples in the upper peat 499 layers, similar relationships describing vertical variations with depth reported in the 500 literature suggest that results from the WTF are reasonable. Results show that this method 501 is a promising tool to quantify $S_{Y}$ and its vertical variation within the water table 502 fluctuation layer of peatlands. The power law apparently provides the best description of $503 \mathrm{~S}_{\mathrm{Y}}$-depth variations.

504 Moreover, site location and seasonality are dominant controls upon water storage 505 capacity, suggesting that both hydroclimatic context and evapotranspiration are of 506 primary importance to understanding peatland water storage capacity. This research has 507 shown that within-site location plays a minor role in $\mathrm{S}_{\mathrm{Y}}$ variations, suggesting that the 508 WTF method could be used to quantify water storage capacity using a single dip well. 509 However, further studies are needed to investigate the influence of microforms (i.e., 510 hummocks, hollows and pools) and hydrogeological context on water storage capacity. 
511 The WTF method is non-invasive, inexpensive, and can easily be used in a wide 512 variety of contexts, since hourly precipitation and peatland water table fluctuation data 513 are commonly measured in peatland monitoring projects. This method provides a 514 relatively simple means of improving the available data on peatland water storage 515 capacity in different conditions, thus contributing to better understand peatland 516 hydrological functions.

\section{Acknowledgments}

518 This research was funded by the Quebec Ministry of Environment (Ministère du 519 Développement durable, de l'Environnement et de la Lutte contre les changements 520 climatiques), by local municipalities, by a scholarship from MITACS Accelerate and the 521 Nature Conservancy of Canada, and by a scholarship from the Fonds de recherche du 522 Québec Nature et technologies (FRQNT). The authors would like to thank the Nature 523 Conservancy of Canada for providing access to the LTF site and private landowners for 524 making their property available for this study (ISO, LCY, SSE, and VIC). Finally, the 525 authors thank Jill Vandermeerschen, the SCAD-UQAM (Service de consultation en 526 analyse de données), Sylvain Gagné, Diogo Barnetche, Marjolaine Roux, and Guillaume 527 Poulin for their statistical, field work and technical support.

\section{References}

529 530

531

532

533

534 535

536

537

538

539

540

541
Acreman M, Holden J. 2013. How Wetlands Affect Floods. Wetlands, 33: 773-786. DOI: 10.1007/s13157-013-0473-2.

Aguilar FJ, Mills JP, Delgado J, Aguilar MA, Negreiros JG, Pérez JL. 2010. Modelling vertical error in LiDAR-derived digital elevation models. ISPRS Journal of Photogrammetry and Remote Sensing, 65: 103-110. DOI: 10.1016/j.isprsjprs.2009.09.003.

Atlas agroclimatique du Québec. 2012. Agro météo Québec: un outil d'aide à la décision et de sensibilisation. In: Agriculture et Agroalimentaire.

Baird AJ, Milner AM, Blundell A, Swindles GT, Morris PJ. 2015. Microform-scale variations in peatland permeability and their ecohydrological implications. J Ecol: 1365-2745. DOI: 10.1111/1365-2745.12530.

Barton CD, Andrews DM, Kolka RK. 2006. Influence of soil physicochemical properties on hydrology and restoration response in Carolina bay wetlands. 447-453. DOI: 10.13031/2013.20342. 
542 Bourgault M, Larocque M, Roy M. 2014. Simulation of aquifer-peatland-river interaction under climate change. Hydrology Research, 45: 425-440. DOI: 10.2166/nh.2013.228.

544 Camporese M, Ferraris S, Putti M, Salandin P, Teatini P. 2006. Hydrological modeling in swelling/shrinking peat soils. Water Resources Research, 42: 1-15. DOI: 10.1029/2005WR004495.

Chiah GJ. 2003. Local random errors in tipping-bucket rain gauge measurements. Journal of Atmospheric and Oceanic Technology, 20: 752-759. DOI: 10.1175/1520-0426(2003)20.

Dettmann U, Bechtold M. 2016. Deriving Effective Soil Water Retention Characteristicsfrom Shallow Water Table Fluctuations in Peatlands. Vadose Zone Journal, 15: 1-13. DOI: 10.2136/vzj2016.04.0029.

Devito KJ, Waddington JM, Branfireun BA. 1997. Flow reversals in peatlands influenced by local groundwater systems. Hydrol Process, 11: 103-110. DOI: Doi 10.1002/(Sici)10991085(199701).

Freeze R, Cherry J. 1979. Groundwater. Old Tappan pp: 604.

Geris J, Tetzlaff D, McDonnell J, Soulsby C. 2015. The relative role of soil type and tree cover on water storage and transmission in northern headwater catchments. Hydrol Process, 29: 1844-1860. DOI: 10.1002/hyp.10289.

Healy R, Cook P. 2002. Using groundwater levels to estimate recharge. Hydrogeol J, 10: 91-109. DOI: 10.1007/s10040-001-0178-0.

Hodgkinson RA, Pepper TJ, Wilson DW. 2004. Evaluation of tipping bucket rain gauge performance and data quality. Agency E (ed.) Environment Agency, Rio House, Waterside Drive, Aztec West, Almondsbury, Bristol, pp: 54.

Hodgson ME, Bresnahan P. 2004. Accuracy of Airborne Lidar-Derived elevation empirical assessment and error budget. Photogrammetric engineering and remote sensing, 70: 331-339.

Holden J. 2009. Flow through macropores of different size classes in blanket peat. Journal of Hydrology, 364: 342-348. DOI: 10.1016/j.jhydrol.2008.11.010.

Holden J, Burt TP, Cox NJ. 2001. Macroporosity and infiltration in blanket peat: the implications of tension disc infiltrometer measurements. Hydrol Process, 15: 289-303. DOI: Doi 10.1002/Hyp.93.

Holden J, Kirkby MJ, Lane SN, Milledge DG, Brookes CJ, Holden V, McDonald AT. 2008. Overland flow velocity and roughness properties in peatlands. Water Resources Research, 44. DOI: Doi 10.1029/2007wr006052.

Ingram HAP, Bragg O. 1984. The diptotelmic mire: some hydrological consequences reviewed. In: Proceedings of the Seventh International Peat Congress, International Peat Society, Dublin, pp: 220-234. 
Jeglum JK. 1991. Definition of Trophic Classes in Wooded Peatlands by Means of Vegetation Types and Plant Indicators. Ann Bot Fenn, 28: 175-192.

Larocque M, Gagné S, Barnetche D, Meyzonnat G, Graveline MH. 2015. Projet de connaissance des eaux souterraines du bassin versant de la zone Nicolet et de la partie basse de la zone Saint-François - Rapport final. pp: 258.

Lefebvre R, Ballard JM, Carrier MA, Vigneault H, Beaudry C, Berthot L, Légaré-Couture G, Parent M, Laurencelle M, Malet X, Therrien A, Michaud A, Desjardins J, Drouin A, Cloutier MH, Grenier J, Bourgault MA, Larocque M, Pellerin S, Graveline MH, Janos D, Molson J. 2015. Portrait des ressources en eau souterraine en Chaudière-Appalaches, Québec, Canada. Projet réalisé conjointement par l'Institut national de la recherche scientifique (INRS), I'Institut de recherche et développement en agroenvironnement (IRDA) et le Regroupement des organismes de bassins versants de la Chaudière-Appalaches (OBVCA) dans le cadre du Programme d'acquisition de connaissances sur les eaux souterraines (PACES), Rapport final INRS R-1580, soumis au MDDELCC en mars 2015., pp: 246.

Letts MG, Roulet N, Comer NT. 2000. Parametrization of peatland hydraulic properties for the Canadian Land surface scheme. Atmosphere-Ocean, 38: 141-160.

McLaughlin DL, Cohen MJ. 2014. Ecosystem specific yield for estimating evapotranspiration and groundwater exchange from diel surface water variation. Hydrol Process, 28: 14951506. DOI: 10.1002/hyp.9672.

McLaughlin DL, Kaplan DA, Cohen MJ. 2014. A significant nexus: Geographically isolated wetlands influence landscape hydrology. Water Resources Research, 50: 7153-7166. DOI: 10.1002/2013WR015002.

Moore PA, Morris PJ, Waddington JM. 2015. Multi-decadal water table manipulation alters peatland hydraulic structure and moisture retention. Hydrol Process, 29: 2970-2982. DOI: 10.1002/hyp.10416.

Nachabe MH. 2002. Analytical expressions for transient specific yield and shallow water table drainage. Water Resources Research, 38: 1-7. DOI: 10.1029/2001WR001071.

Pasquet S, Pellerin S, Poulin M. 2015. Three decades of vegetation changes in peatlands isolated in an agricultural landscape. Appl Veg Sci, 18: 220-229. DOI: 10.1111/avsc.12142.

Price JS. 1996. Hydrology and microclimate of a partly restored cutover bog, Quebec. Hydrol Process, 10: 1263-1272. DOI: 10.1002/(SICI)1099-1085(199610)10:10<1263::AIDHYP458>3.0.CO;2-1.

R DCT. 2008. R: A language and encironment for statistical computing. Vienna, Autria, ISBN 3900051-07-0.

Ramirez JA, Baird AJ, Coulthard TJ, Waddington JM. 2015. Ebullition of methane from peatlands: Does peat act as a signal shredder? Geophys Res Lett, 42: 3371-3379. DOI: 10.1002/2015GL063469. 
616 Reeve AS, Evensen R, Glaser PH, Siegel DI, Rosenberry D. 2006. Flow path oscillations in 617 transient ground-water simulations of large peatland systems. Journal of Hydrology, 618 316: 313-324. DOI: 10.1016/j.jhydrol.2005.05.005.

619 Reeve AS, Siegel DI, Glaser PH. 2000. Simulating vertical flow in large peatlands. Journal of 620 Hydrology, 227: 207-217. DOI: 10.1016/S0022-1694(99)00183-3.

Reeve AS, Siegel DI, Glaser PH. 2001. Simulating dispersive mixing in large peatlands. Journal of Hydrology, 242: 103-114. DOI: 10.1016/S0022-1694(00)00386-3.

Richard PJH, Occhietti S. 2004. Meltwater discharge and the triggering of Younger Dryas : new data on the chronology of Champlain Sea transgression in the St-Lawrence River Valley. EOS (Transactions, American Geophysical Union), 85: GC12A-01.

Ronkanen AK, Klove B. 2008. Hydraulics and flow modelling of water treatment wetlands constructed on peatlands in Northern Finland. Water Res, 42: 3826-3836. DOI: 10.1016/j.watres.2008.05.008.

Rosa E, Larocque M. 2008. Investigating peat hydrological properties using field and laboratory methods: application to the Lanoraie peatland complex (southern Quebec, Canada). Hydrol Process, 22: 1866-1875. DOI: 10.1002/Hyp.6771.

Sherwood JH, Kettridge N, Thompson DK, Morris PJ, Silins U, Waddington JM. 2013. Effect of drainage and wildfire on peat hydrophysical properties. Hydrol Process, 27: 1866-1874. DOI: 10.1002/hyp.9820.

Turner E, Baird A, Billett M, Chapman P, Dinsmore K, Holden J. 2015. Water movement through blanket peat is dominated by a complicated pattern of near-surface flows. EGU General Assembly, 17: 3146-3141.

Von Post L. 1922. Sveriges Geologiska Undersoknings torvinventering och nogra av dess hittils vunna resultat (SGU peat inventory and some preliminary results). Svenska Mosskulturforeningens Tidskrift, Jonkoping, Sweden: 1-37.

641 Vorob'ev PK. 1963. Investigations of water yield of low lying swamps of western Siberia. 642 Transactions of the states hydrologic institute: 45-79.

643 Waddington JM, Morris PJ, Kettridge N, Granath G, Thompson DK, Moore PA. 2015. Hydrological

Winter TC, Harvey JW, Franke OL, Alley WM. 1998. Ground water and surface water: a single changes in Illinois using the Gravity Recovery and Climate Experiment (GRACE). Water Resources Research, 42: 7. DOI: 10.1029/2006WR005374. 
Table I Site descriptions: coordinate, altitude, area, distance and mean slope between up-gradient and down-gradient location, watershed, lithology, dominant species, annual evapotranspiration and difference between precipitation (P) and evapotranspiration (ETP). 
Table II Specific yield measurements in wetlands as reported in the literature.

\begin{tabular}{|c|c|c|c|c|c|c|c|}
\hline Sy & $\begin{array}{c}\text { Rate } \\
\text { decrease } \\
\left(\mathrm{cm}^{-1}\right)\end{array}$ & Method & Author & Main objective & $\begin{array}{l}\text { Wetland } \\
\text { type }\end{array}$ & $\begin{array}{l}\text { depth } \\
\text { (cm) }\end{array}$ & year \\
\hline $0-0.9$ & $\approx 0-0.08$ & WTF & $\begin{array}{l}\text { Dettmann and } \\
\text { Bechtold } 2016\end{array}$ & methological development & peatland & $0-45$ & 2016 \\
\hline $0-1.1$ & $0.007-0.013$ & WTF & $\begin{array}{l}\text { Moore et al. } \\
2015\end{array}$ & site-depth-microforms & peatland & $0-65$ & 2015 \\
\hline $0.1-0.7$ & $0.007-0.013$ & Pressure chamber & $\begin{array}{l}\text { Moore et al. } \\
2015\end{array}$ & site-depth-microforms & peatland & $0-50$ & 2015 \\
\hline $0.13-1.05$ & 0.02 & WTF & $\begin{array}{l}\text { McLaughlin and } \\
\text { Cohen } 2014\end{array}$ & $\begin{array}{c}\text { evapotranspiration and } \\
\text { groundwater exchange } \\
\text { estimation }\end{array}$ & open water & $\begin{array}{c}50-0 \\
\text { (above } \\
\text { surface) }\end{array}$ & 2014 \\
\hline $0.05-0.4$ & NA & WTF & $\begin{array}{l}\text { McLaughlin and } \\
\text { Cohen } 2014\end{array}$ & $\begin{array}{c}\text { evapotranspiration and } \\
\text { groundwater exchange } \\
\text { estimation }\end{array}$ & open water & $\begin{array}{l}60-0 \\
\text { (above } \\
\text { surface) }\end{array}$ & 2014 \\
\hline $0-0.85$ & NA & Pressure chamber & $\begin{array}{l}\text { Thompson and } \\
\text { Waddington } \\
2013\end{array}$ & $\begin{array}{l}\text { microforms-depth-density- } \\
\text { wildfire alteration }\end{array}$ & peatland & $0-45$ & 2013 \\
\hline $0.01-1$ & $0.02-0.05$ & Infiltrometer & Holden 2009 & depth-cover type & $\begin{array}{c}\text { upland } \\
\text { blanket peat }\end{array}$ & $0-20$ & 2009 \\
\hline 0.23 & NA & $\begin{array}{l}\text { Gravity } \\
\text { (experimental } \\
\text { tank) }\end{array}$ & $\begin{array}{c}\text { Rosa and } \\
\text { Larocque } 2008\end{array}$ & $\begin{array}{l}\text { peat hydrological } \\
\text { properties }\end{array}$ & peatland & $0-40$ & 2009 \\
\hline $0.75-0.99$ & NA & Tracer tests & $\begin{array}{l}\text { Ronkanen and } \\
\text { Klove } 2008\end{array}$ & $\begin{array}{l}\text { modelling of water } \\
\text { treatment wetlands }\end{array}$ & $\begin{array}{l}\text { contructed } \\
\text { peatland }\end{array}$ & NA & 2008 \\
\hline $0.13-0.66$ & NA & Gravity & Lett et al 2000 & $\begin{array}{l}\text { depth - humification - } \\
\text { modelling WT variation }\end{array}$ & peatland & $0-35$ & 2000 \\
\hline $0.25-0.55$ & $\approx 0.01$ & Gravity & Price, 1996 & $\begin{array}{l}\text { effect of peat harvesting } \\
\text { on water balance }\end{array}$ & peatland & $0-55$ & 1996 \\
\hline $0.04-0.06$ & $\approx 0$ & Gravity & Price, 1996 & $\begin{array}{l}\text { effect of peat harvesting } \\
\text { on water balance }\end{array}$ & cutover bog & $0-62$ & 1996 \\
\hline $0.1-0.55$ & $\approx 0-0.015$ & Gravity & Price 1992 & $\begin{array}{l}\text { water budget - } \\
\text { hydrological processes }\end{array}$ & blanket bog & $0-250$ & 1992 \\
\hline $0.09-0.45$ & $0.04-0.06$ & Gravity & Vorob.ev. 1963 & depth-cover type & $\begin{array}{l}\text { swamp } \\
\text { (peat) }\end{array}$ & $0-20$ & 1963 \\
\hline
\end{tabular}






Figure 1 Locations of the five studied peatlands in the Châteauguay (LTF), Nicolet (SSE, LCY, and VIC), and Du Chêne (ISO) watersheds of southern Québec (Canada).

Figure 1

$223 \times 150 \mathrm{~mm}(300 \times 300$ DPI $)$ 


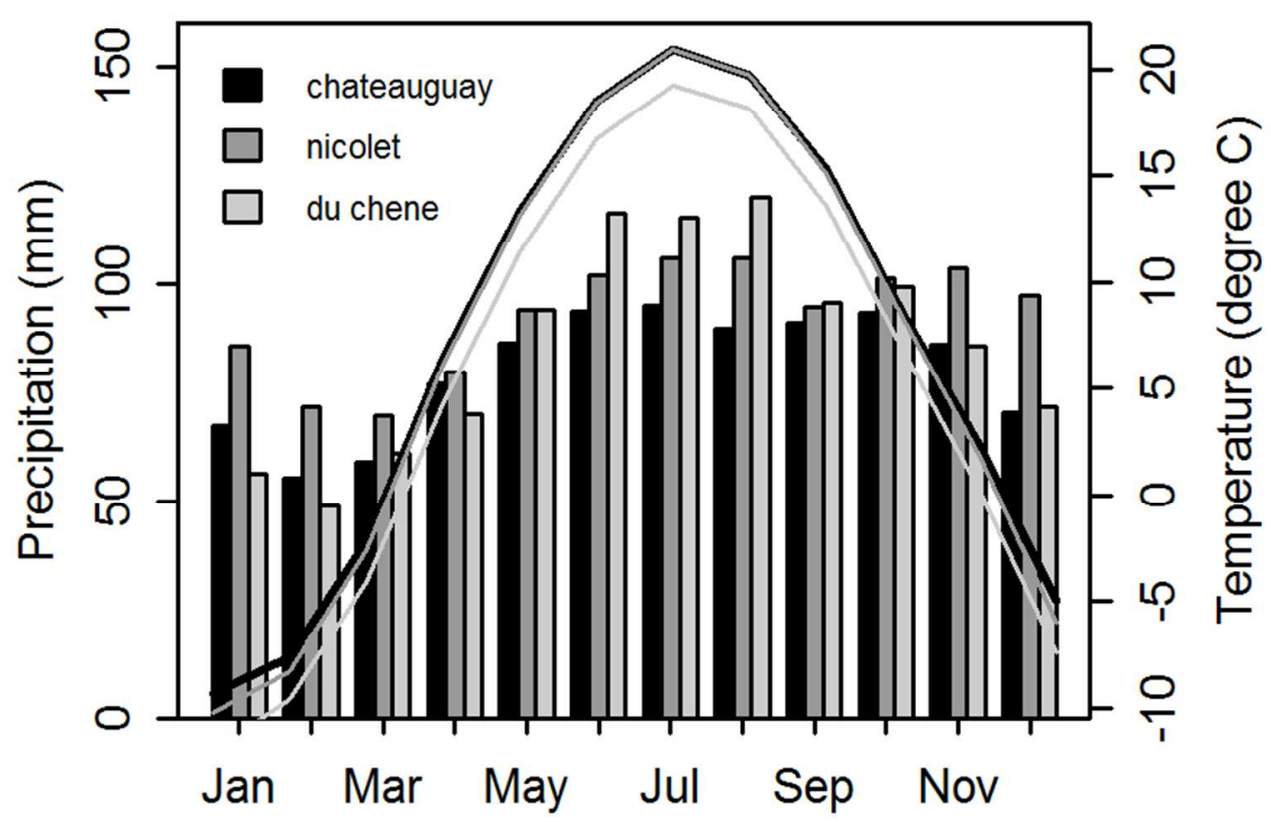

Figure 2 Mean monthly precipitation (bars) and temperature (lines) between 1981 and 2010 for Châteauguay (black), Nicolet (grey), and du Chêne (light grey) watersheds. Note that temperatures curves for Châteauguay and Nicolet overlap or nearly overlap for much of the year.

Figure 2

$76 \times 60 \mathrm{~mm}(300 \times 300 \mathrm{DPI})$ 
Figure 3 Up-gradient, mid-gradient, and down-gradient locations of the instrumented wells in the studied peatlands. Black arrows show general water circulation patterns.

Figure 3

$39 \times 21 \mathrm{~mm}(600 \times 600 \mathrm{DPI})$ 
Figure 4 Design of the experimental tank with an impermeable base support built for the drainage experiment to calculate specific yield variations with depth (modified from Rosa and Larocque, 2008). Figure 4

$45 \times 31 \mathrm{~mm}(600 \times 600 \mathrm{DPI})$ 


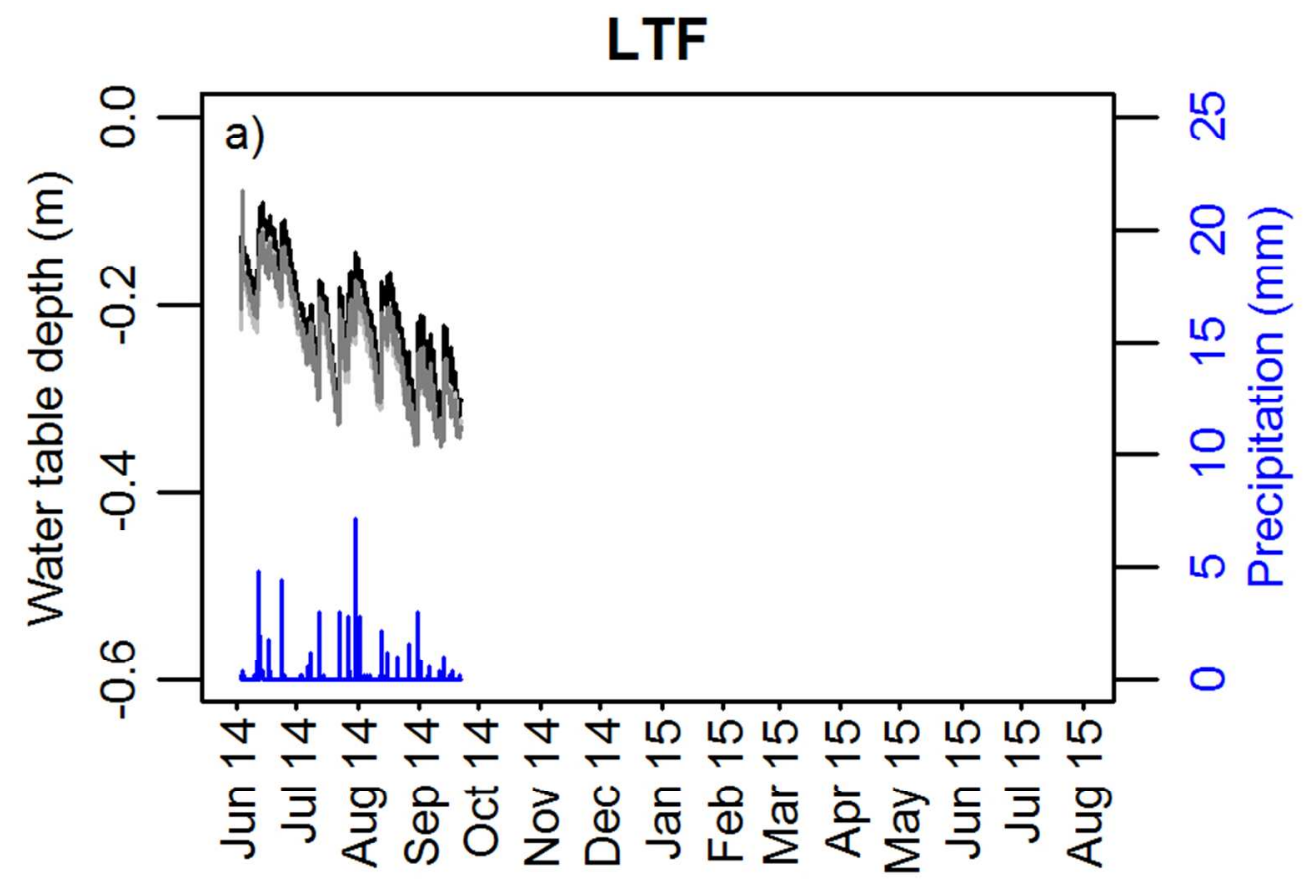

Figure 5 Water table depths and precipitation from June 2014 to August 2015 at the up-gradient (black), mid-gradient (grey), and down-gradient (light grey) locations at a) Large Tea Field (LTF), b) SainteSéraphine (SSE), c) Lac Cyprès (LCY), d) Victoriaville (VIC), and e) Issoudun (ISO). The period without data corresponds to the winter season. The LTF time series is only from June to September 2014 due to technical difficulties with the pluviometer in the summer 2015.

\section{Figure 5}

$76 \times 60 \mathrm{~mm}(300 \times 300 \mathrm{DPI})$ 
Figure 5 Water table depths and precipitation from June 2014 to August 2015 at the up-gradient (black), mid-gradient (grey), and down-gradient (light grey) locations at a) Large Tea Field (LTF), b) SainteSéraphine (SSE), c) Lac Cyprès (LCY), d) Victoriaville (VIC), and e) Issoudun (ISO). The period without data corresponds to the winter season. The LTF time series is only from June to September 2014 due to technical difficulties with the pluviometer in the summer 2015.

\section{Figure 5}

$76 \times 60 \mathrm{~mm}(300 \times 300 \mathrm{DPI})$ 


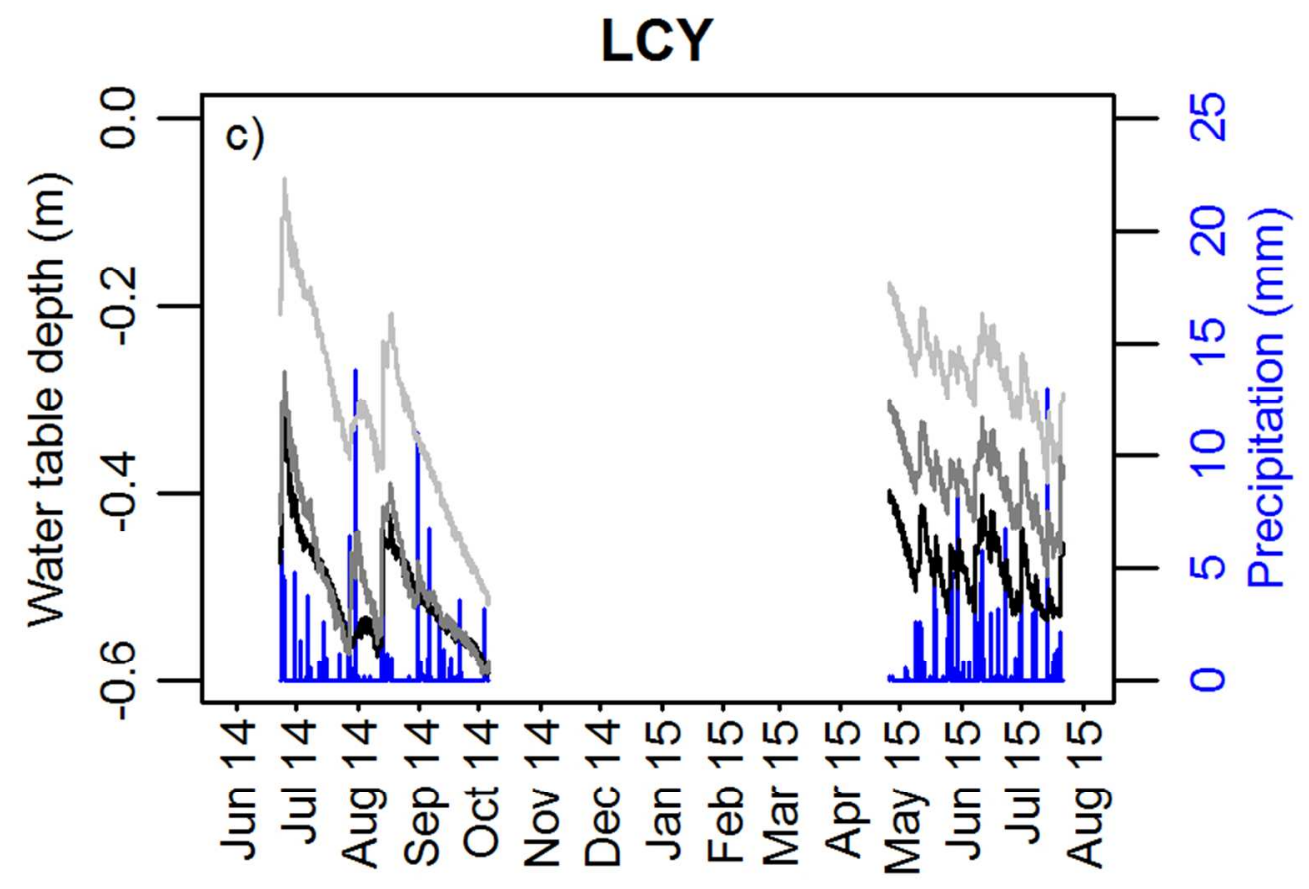

Figure 5 Water table depths and precipitation from June 2014 to August 2015 at the up-gradient (black), mid-gradient (grey), and down-gradient (light grey) locations at a) Large Tea Field (LTF), b) SainteSéraphine (SSE), c) Lac Cyprès (LCY), d) Victoriaville (VIC), and e) Issoudun (ISO). The period without data corresponds to the winter season. The LTF time series is only from June to September 2014 due to technical difficulties with the pluviometer in the summer 2015.

\section{Figure 5}

$76 \times 60 \mathrm{~mm}(300 \times 300 \mathrm{DPI})$ 
Figure 5 Water table depths and precipitation from June 2014 to August 2015 at the up-gradient (black), mid-gradient (grey), and down-gradient (light grey) locations at a) Large Tea Field (LTF), b) SainteSéraphine (SSE), c) Lac Cyprès (LCY), d) Victoriaville (VIC), and e) Issoudun (ISO). The period without data corresponds to the winter season. The LTF time series is only from June to September 2014 due to technical difficulties with the pluviometer in the summer 2015.

\section{Figure 5}

$76 \times 60 \mathrm{~mm}(300 \times 300 \mathrm{DPI})$ 


\section{ISO}

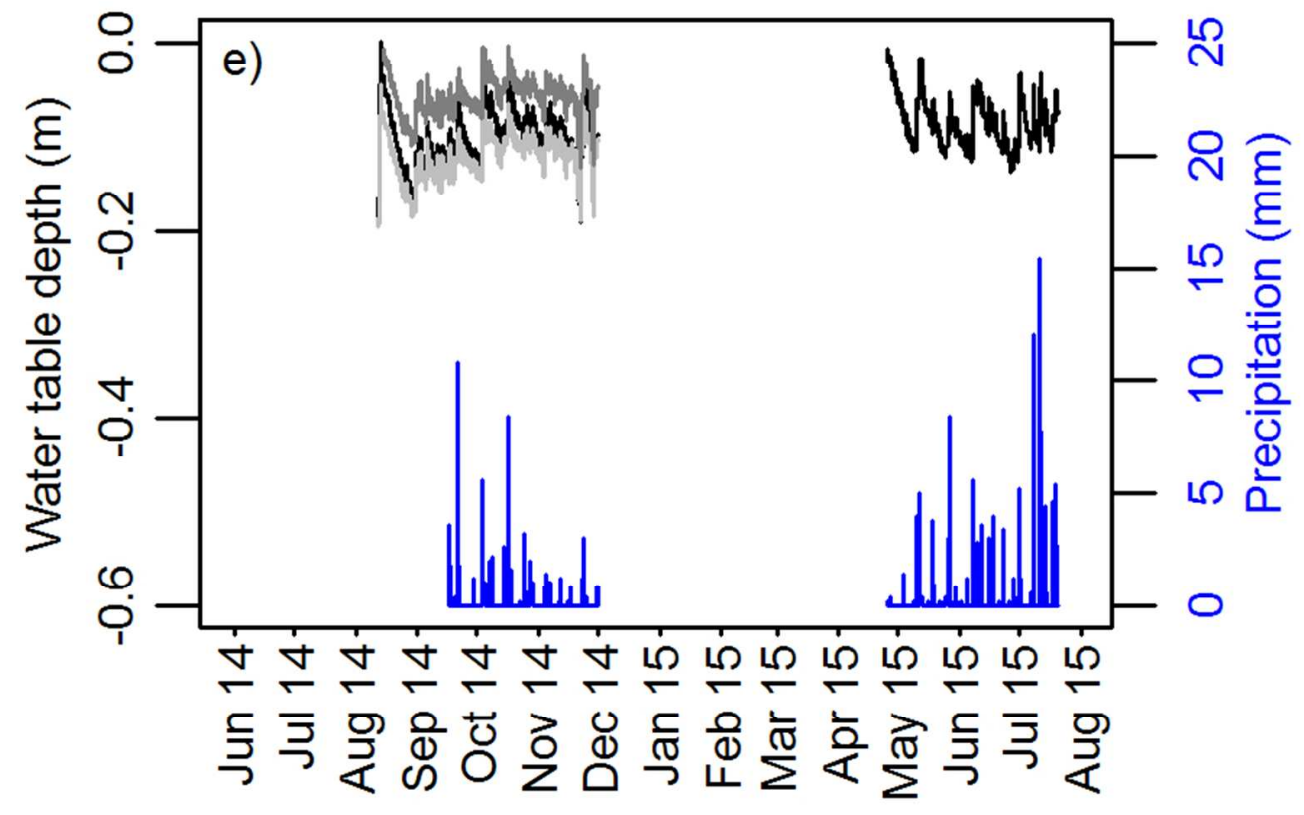

Figure 5 Water table depths and precipitation from June 2014 to August 2015 at the up-gradient (black), mid-gradient (grey), and down-gradient (light grey) locations at a) Large Tea Field (LTF), b) SainteSéraphine (SSE), c) Lac Cyprès (LCY), d) Victoriaville (VIC), and e) Issoudun (ISO). The period without data corresponds to the winter season. The LTF time series is only from June to September 2014 due to technical difficulties with the pluviometer in the summer 2015.

\section{Figure 5}

$76 \times 60 \mathrm{~mm}(300 \times 300 \mathrm{DPI})$ 


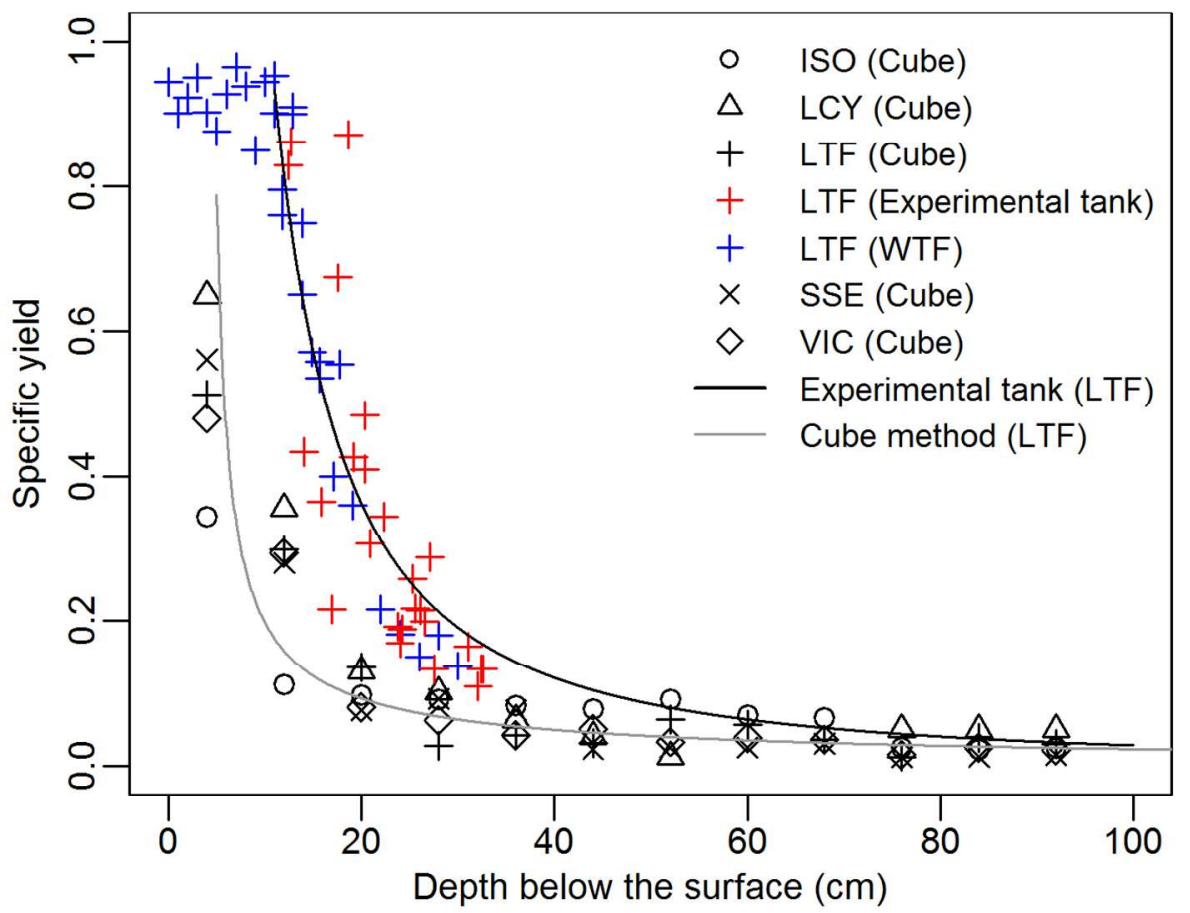

Figure 6 Variation in specific yield (SY) with depth using the small cube (mean values are plotted for each site), experimental tank (LTF only) and WTF (LTF only) methods. The black line shows the SY-depth relationship using the experimental tank method (LTF) and the grey line shows the logarithmic SY-depth relationship using the cube method (LTF).

Figure 6

$127 \times 101 \mathrm{~mm}(300 \times 300$ DPI) 




Figure 7 Water table variation $(\Delta h)$ as a function of precipitation $(P)$ for all sites and locations. Each point represents a single precipitation event. Dashed lines and associated value represent the ratio of $P / \Delta h$ equivalent to SY.

Figure 7

$76 \times 50 \mathrm{~mm}(300 \times 300$ DPI $)$ 
Figure 8 Variation in specific yield estimated using the power law model applied to the WTF method as a function of depth below the surface for all peatlands and all locations (up-gradient, mid-gradient and downgradient).

Figure 8

$152 \times 101 \mathrm{~mm}(300 \times 300 \mathrm{DPI})$ 


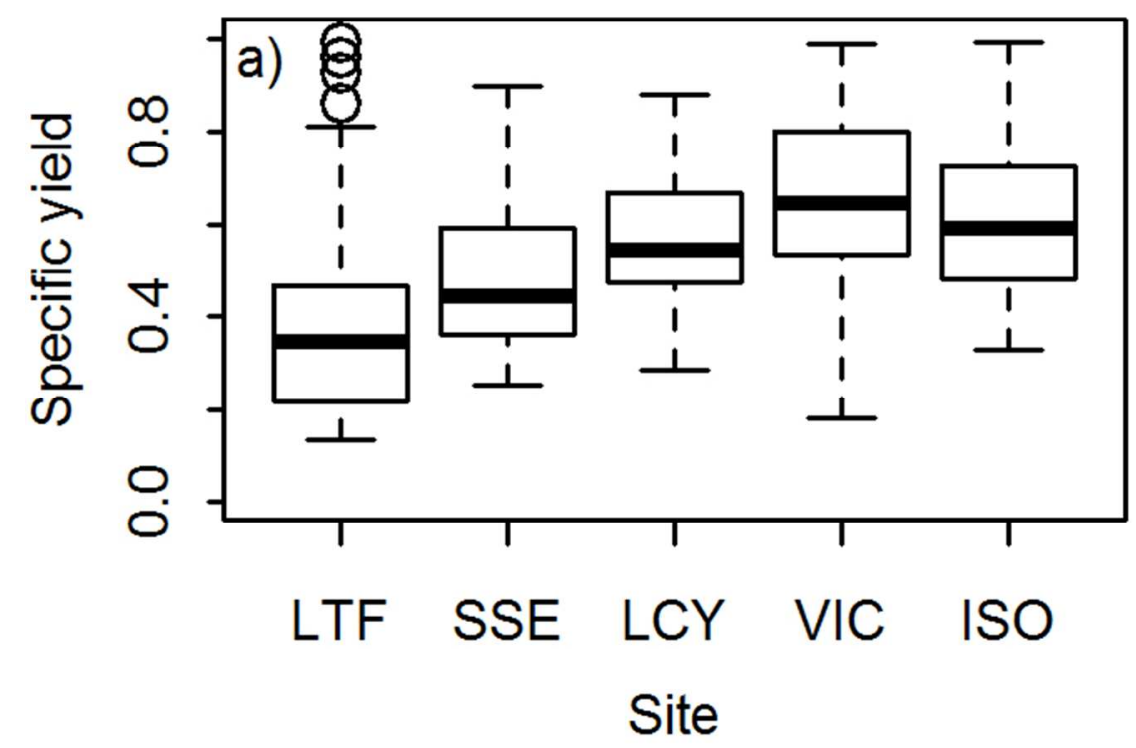

Figure 9 Influence of a) site, b) depth below the surface, c) seasonality (May to November), and d) withinsite location on specific yield found using the WTF method. Each box plot shows the minimum (lower bar), the first quartile (lower portion of the box), the median (bold black line), the third quartile (higher portion of the box), the maximum (upper bar), and the outliers (circles). Figure 9

$66 \times 50 \mathrm{~mm}(300 \times 300 \mathrm{DPI})$ 


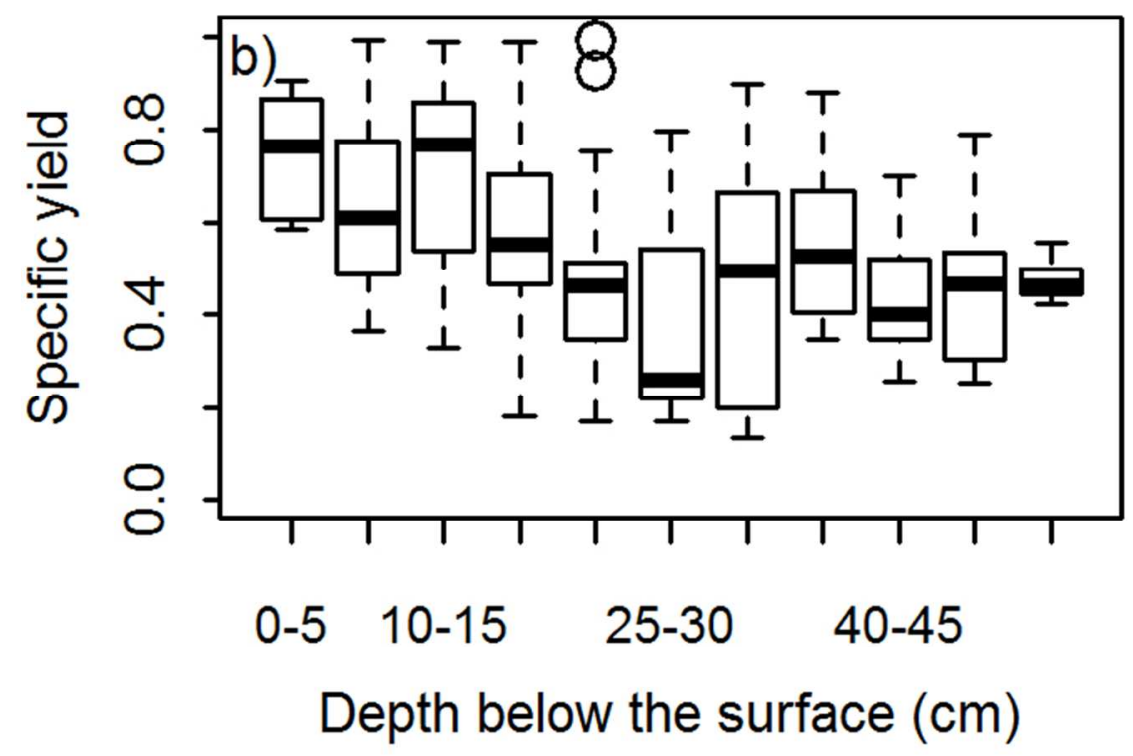

Figure 9 Influence of a) site, b) depth below the surface, c) seasonality (May to November), and d) withinsite location on specific yield found using the WTF method. Each box plot shows the minimum (lower bar), the first quartile (lower portion of the box), the median (bold black line), the third quartile (higher portion of the box), the maximum (upper bar), and the outliers (circles).

Figure 9

$66 \times 50 \mathrm{~mm}(300 \times 300 \mathrm{DPI})$ 


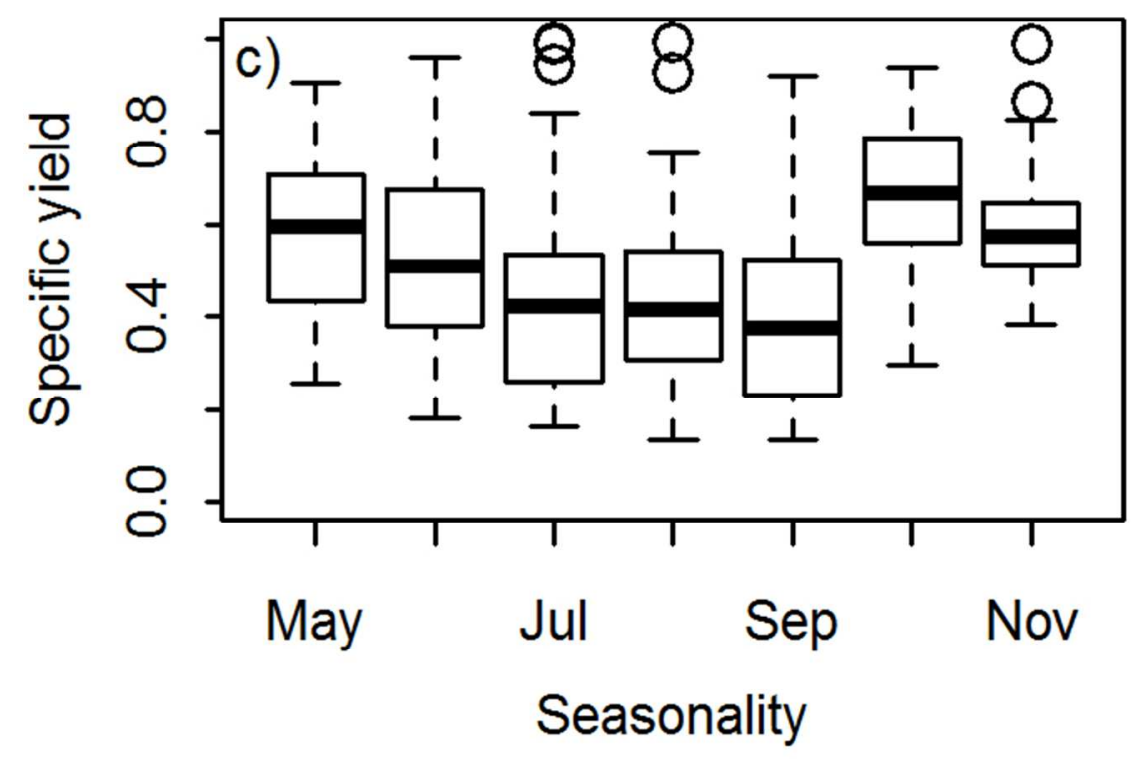

Figure 9 Influence of a) site, b) depth below the surface, c) seasonality (May to November), and d) withinsite location on specific yield found using the WTF method. Each box plot shows the minimum (lower bar), the first quartile (lower portion of the box), the median (bold black line), the third quartile (higher portion of the box), the maximum (upper bar), and the outliers (circles). Figure 9

$66 \times 50 \mathrm{~mm}(300 \times 300 \mathrm{DPI})$ 


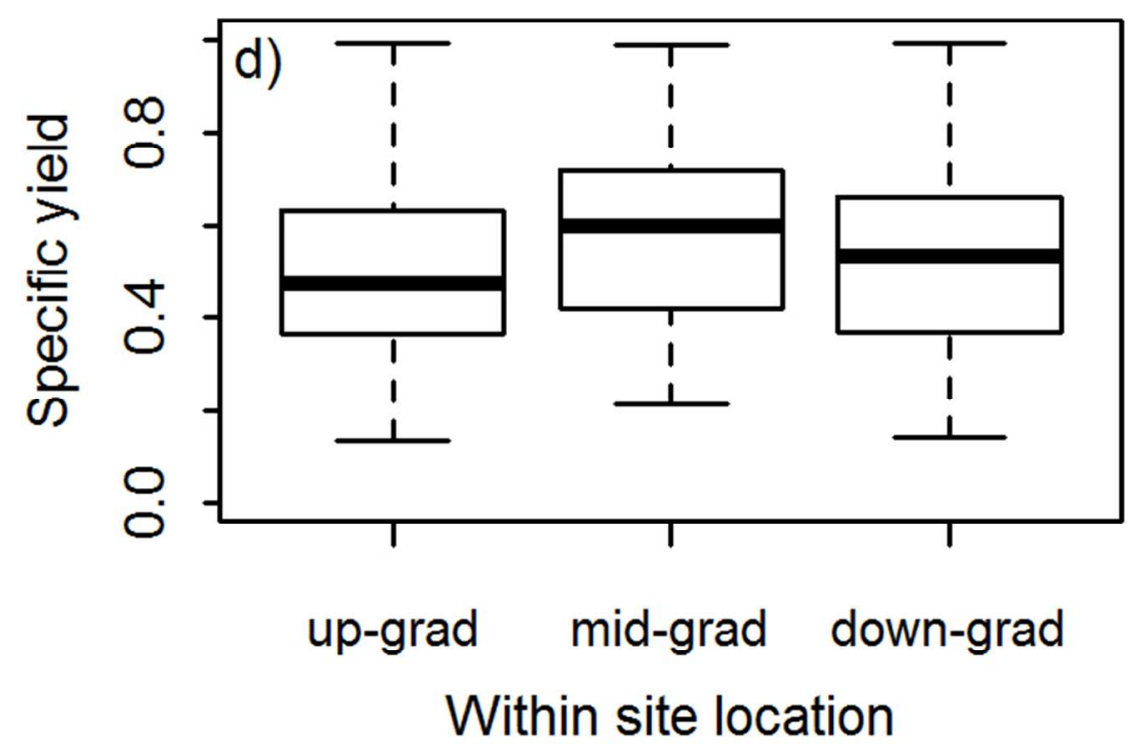

Figure 9 Influence of a) site, b) depth below the surface, c) seasonality (May to November), and d) withinsite location on specific yield found using the WTF method. Each box plot shows the minimum (lower bar), the first quartile (lower portion of the box), the median (bold black line), the third quartile (higher portion of the box), the maximum (upper bar), and the outliers (circles).

Figure 9

$66 \times 50 \mathrm{~mm}(300 \times 300 \mathrm{DPI})$ 